Vol. 7(1998): 391-399.

\title{
The Nordic Gene Bank's Prunus clone archive in Finland I Local races of sour cherry
}

\author{
Pauliina Palonen \\ Department of Plant Production, PO Box 27, FIN-00014 University of Helsinki, \\ Finland, e-mail: pauliina.palonen@helsinki.fi \\ Marjatta Uosukainen \\ Agricultural Research Centre of Finland, Laukaa Research and Elite Plant Station, Antinniementie 1, \\ FIN-41330 Vihtavuori, Finland \\ Eeva Laurinen \\ Agricultural Research Centre of Finland, Horticulture, Toivonlinnantie 518, FIN-21500 Piikkiö, Finland \\ Päivi Parikka \\ Agricultural Research Centre of Finland, Plant Protection, FIN-31600 Jokioinen, Finland \\ Jyri Kankila \\ Department of Plant Biology, PO Box 27, FIN-00014 University of Helsinki, Finland
}

\begin{abstract}
Morphological variation among 78 local races of sour cherry (Prunus cerasus L.) in the Nordic Gene Bank's Prunus clone archive in Pälkäne in Southwestern Finland was examined. Each tree was described using 42 characteristics. On the basis of fruit characteristics, 32 samples were classified as morellos, 40 samples as amarelles, and 5 samples distinct from the other amarelles are proposed to be called Rymättylä-type cherries. One sample was found to be Prunus avium. Amarelle type cherries proved to be more self compatible than morello type cherries. In order to find hardy sour cherry cultivars with fruits of good flavour and fit for cultivation in Nordic conditions, the most promising local races from each group were selected for a comparative trial. Additionally, some local races were selected for further use in plant breeding. In 1994-1996, an increasing amount of severe bacterial canker symptoms was observed in the clone achive.
\end{abstract}

Key words: amarelle, morello, Prunus cerasus, Rymättylä, self-compatibility

\section{Introduction}

The Nordic Gene Bank (NGB), founded in 1979, records and preserves genetic variation in valu- able agricultural and horticultural plant materi$\mathrm{al}$ in the Nordic countries. The horticultural crops are mainly vegetatively propagated, and must, therefore, be preserved on their original growing sites (in situ), or in Gene Bank clone archives

(C) Agricultural and Food Science in Finland

Manuscript received June 1997 


\section{AGRICULTURAL AND FOOD SCIENCE IN FINLAND}

Palonen, P. et al. Prunus clone archive in Finland: sour cherry

(ex situ) (Trajkovski et al. 1992). The aim of the Prunus project of the Nordic Gene Bank is to find sour cherry, plum and damson plum cultivars adapted to Nordic conditions, and to find local races, which could be cultivated as such, or used in breeding. Besides being used in fruit production, cherry, plum and damson plum trees are also excellent ornamentals.

Sour cherry (Prunus cerasus L.) has been cultivated in Finland since the 17th century (Collan 1929). In 1929, after an exceptionally hard winter, it was found that in total 21 cherry cultivars existed in Finland (Collan 1934). In the past, cherry trees were imported to Finland from Russia, Estonia, Germany and Sweden (Collan 1929). The oldest known cultivars in Finland are 'Yleinen kuulasmarja' ('Common amarelle'), 'Iso kuulasmarja' ('Big amarelle') and 'Varjomorelli' (known as 'Schattenmorelle' in Germany and 'Skuggmorell' in Sweden) (Meurman 1947). The trees have been open pollinated freely, and new offspring generated from seeds have been propagated and distributed through root suckers. Due to the decades of long natural selection and adaptation to harsh conditions, the hardiest germplasm available is most probably to be found among the native cultivars.

An understanding of phenotypic and genetic variation in sour cherry is important for cultivar development, future germplasm collection, and setting of priorities for germplasm maintenance (Hillig and Iezzoni 1988). The objective of this study was to examine the morphological variation in local races of sour cherry in the Nordic Gene Bank's Prunus clone archive at the Agricultural Research Centre of Finland, Häme Research Station in Pälkäne, and to select the most promising local races for a comparative trial, starting in 1994.

\section{Material and methods}

The local races of sour cherry, plum and damson plum were registered during 1982-85, main- ly in Southern and Southeastern Finland including the Åland Islands. From every individual Prunus tree, registered on the Finnish mainland, at least two root suckers were taken and transported to the Agricultural Research Centre of Finland, Institute of Horticulture in Piikkiö, where they were planted in a temporary location. In 1988, duplicates of each local race were sent to Pälkäne ( $\left.61^{\circ} 20^{\prime} \mathrm{N}, 24^{\circ} 13^{\prime} \mathrm{E}\right)$, where trees were planted on an experimental field with sandy soil at a spacing of 3 metres within and 4 metres between rows. The local races originating in the Åland Islands were placed in a Prunus clone archive at Åland Experiment Station in Jomala.

In Pälkäne, disease symptoms were observed, but no plant protection chemicals were used in the Prunus orchard. $300 \mathrm{~kg}$ of compound fertilizer (NPK 7-5-15) per hectare was applied annually. Every tree was protected against meadow voles with a plastic shield. Weeding was carried out by mowing or harrowing, when needed. Root suckers were removed annually. The trees were not pruned.

Documentation of cherry material in the Prunus clone archive in Pälkäne was carried out during each season between 1992 and 1993. In 1992, the Prunus clone archive consisted of 122 sour cherry trees, representing 79 different local races, and in 1993, of 118 trees, representing 78 different local races. Each tree was described by the characteristics used by the Nordic Gene Bank. The descriptions were complemented with some further characteristics used by the International Union for the Protection of New Varieties of Plants (UPOV). In total 42 characteristics were used for the description of each tree. Characteristics observed were related to growth habit, flowering, fruit set, as well as the external and internal properties of the fruits. The descriptions were made mainly in 1992 and complemented in 1993. The descriptions will be saved in the Nordic Gene Bank's database BIRS.

In 1992 and 1993, the self-compatibility of local races of sour cherry was studied. In 1992, 30 local races were selected for the self-compatibility studies. Three branches per tree were isolated before floral anthesis by enclosing them 


\section{AGRICULTURAL AND FOOD SCIENCE IN FINLAND}

Vol. 7 (1998): 391-399.

in acrylic bags. Additionally, some branches were collected from each tree, and forced to flower. Pollen was collected and the isolated flowers were self-pollinated. Also, three branches per tree were marked and allowed to open pollinate.

In 1993, the pollination experiments were limited to 20 local races selected in the previous year. Two branches per tree were isolated with acrylic bags, and two branches were marked and used as open pollinated controls. Self-pollination was aided by brushing the isolated flowers carefully with a small clean brush, as the pollen was dehisced. This was carried out daily during the flowering period.

The number of self-pollinated flowers and the number of open-pollinated flowers were counted, and in early July, the number of green fruits was recorded. The percentages of fruit set on self-pollinated and on open pollinated branches were calculated. The self-compatibility comparisons were made in two different ways; based on the geographic origin of the local races, and based on their fruit type classification. The selfcompatibility of Eastern and Western local races was compared in 1992, and the self-compatibility of local races, belonging to different main groups, in 1993. The ratio of percentage fruit set with self-pollination to that with open pollination describes the self-compatibility of each local race. The data on the ratios were analysed with ANOVA-1-test of MSTAT-C -program (Michigan State University 1989).

All the local races of sour cherry were evaluated for their possible further use. The main criteria were: ornamental value, fruit set, fruit quality, winter-hardiness and resistance to diseases and pests. Each local race was either recommended for further study or determined to be of no value. In order to find hardy sour cherry cultivars with fruits of good flavour and fit for cultivation in Nordic conditions, the most promising local races from each group were selected for a comparative trial and some for possible further use in plant breeding.

\section{Results}

Although trees flowered freely in 1992, the yield was low, and the harvesting period was lengthened because of the cool weather. In 1993, the flowering season was very early because of the extremely warm weather in May and the period of flowering varied from 12 May to 29 May. The differences in earliness of flowering were negligible among the clones. On average, the yield was very high and the fruits were of good quality. The fruits were harvested from 28 July to 13 August.

On the basis of their fruit characteristics the local races of sour cherry were classified into three main groups (Table 1). One local race was found to be Prunus avium.

Group 1. Morello cherries. Fruits are very dark, nearly black when mature. The mean weight of the fruits was $2.4 \mathrm{~g}$ in 1993. The stalk is fairly long. Fruit flesh and juice are dark red. The cherries are very aromatic but mostly extremely bitter. The trees have long and weak branches, with bare parts on them. Because of their high content of acids, intense juice colour and strong aroma, the fruits are suitable for conserving and for use in the food processing industry.

Group 2. Amarelle cherries. Fruit colour is red or dark red. The mean weight of the fruits was $2.5 \mathrm{~g}$ in 1993. The stalk is of medium length. Fruit flesh is yellowish pink and juice is colourless or pink. At maturity, the fruit skin is often nearly translucent. The cherries are relatively sweet or slightly bitter, and less aromatic than morellos. The fruits are suitable for fresh consumption. The trees may be big and bush-like or small with a decorative form.

Group 3. Rymättylä-type cherries. The sour cherry races of this group resemble amarelle cherries, except that the fruits tend to be bigger and flatter. The stalk is typically short, thick and rather stiff. The mean weight of the fruits was $2.8 \mathrm{~g}$ in 1993. Fruit colour is red. The cherries are proposed to be called Rymättylä-type, as they have been registered in Rymättylä or its sur- 


\section{AGRICULTURAL AND FOOD SCIENCE IN FINLAND}

Palonen, $P$. et al. Prunus clone archive in Finland: sour cherry

Table 1. Local races of sour cherry, selected for further study. The races are divided into the three main groups of the Finnish sour cherry.

\begin{tabular}{|c|c|c|}
\hline Morello cherries & Amarelle cherries & Rymättylä type \\
\hline 7 Rymättylä & Myttäälän hapankirsikka & 4 Rymättylä \\
\hline 35 Parainen & 12 Tammela & 5 Rymättylä \\
\hline 87 Laukaa & 19 Somero & $10 ?$ \\
\hline 107 Mäntsälä & 24 Masku & 37 Turku \\
\hline 110 Virojoki & 30 Tenhola & 66 Sammatti \\
\hline 112 Vehkalahti & 43 Kustavi & \\
\hline 114 Lappeenranta & 52 Tuusula & \\
\hline 116 Joutseno & 54 Vantaa & \\
\hline 121 Juva & 74 e, Lohja mlk & \\
\hline 122 Juva & $85 ?$ & \\
\hline 123 Juva & $86 ?$ & \\
\hline 125 Pertunmaa & 91 Nurmijärvi & \\
\hline 129 Anjalankoski & 92 Loppi & \\
\hline 134 Pertunmaa & 93 Kärkölä & \\
\hline 141 Anttola & 95 Hollola & \\
\hline \multirow[t]{19}{*}{142 Puumala } & 96 Hollola & \\
\hline & 98 Asikkala & \\
\hline & 101 Kuusankoski & \\
\hline & 102 Koria & \\
\hline & 104 Kotka & \\
\hline & 105 Lapinjärvi & \\
\hline & 108 Mäntsälä & \\
\hline & 109 Pyhtää & \\
\hline & 124 Mikkeli mlk. & \\
\hline & 131 Lahti & \\
\hline & 133 Pertunmaa & \\
\hline & 137 Laukaa & \\
\hline & 139 Toivakka & \\
\hline & 140 Kangasniemi & \\
\hline & 143 Anttola & \\
\hline & 144, Anttola & \\
\hline & 146 Joroinen & \\
\hline & 160 Mikkeli mlk. & \\
\hline & $301 ?$ & \\
\hline
\end{tabular}

roundings in Southwestern Finland. Their origins are not known.

The local races of morello cherries were found growing mainly in Eastern Finland. The distribution of local races of amarelle cherries is more western. These two types meet each other in the area between $26^{\circ}$ and $27^{\circ}$ of eastern longitude. In the clone archive, the most northern samples of both types were found growing in Laukaa $\left(62^{\circ} 20^{\prime} \mathrm{N}\right)$. However, after the NGB collection was completed in 1988 , two more sam- ples were registered even further north. The most northern morello sample was found from Tuusniemi $\left(62^{\circ} 45^{\prime} \mathrm{N}\right)$ (R. Teravuo, personal communication, 1993), and the most northern amarelle sample from Pihtipudas $\left(63^{\circ} 15^{\prime} \mathrm{N}\right)$ (M. Raatikainen, personal communication, 1992). These two samples were added to the clone archive in 1995.

In 1992, the percentage of fruit set varied with self-pollination from 0 to 18 , the average being 4.3 , and with open pollination from 3 to 24 , the average being 10.7 (Table 2 and Fig- 


\section{AGRICULTURAL AND FOOD SCIENCE IN FINLAND}

Vol. 7 (1998): 391-399.

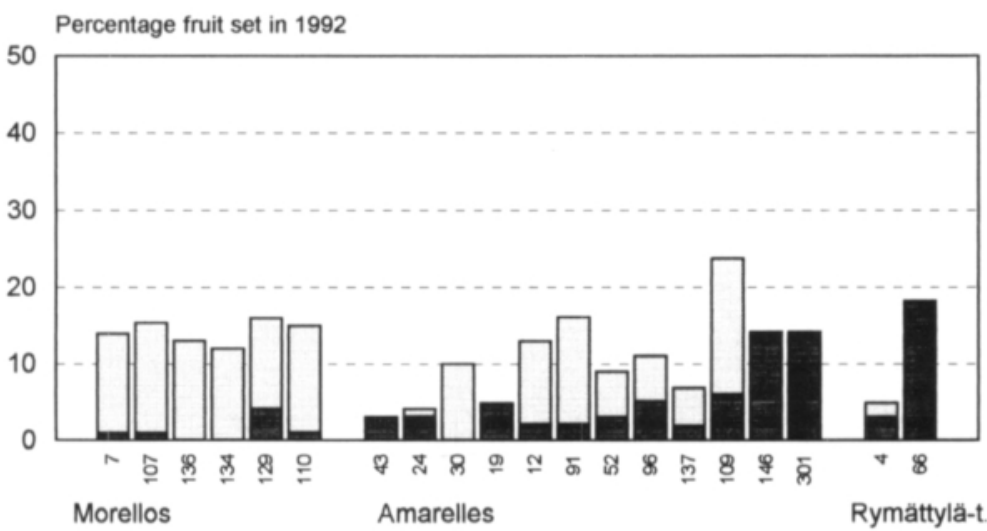

Fig 1. Self-compatibility of local sour cherry races in different main groups presented as percentage fruit set by self-pollination and open pollination in 1992 and 1993. Within each group, local races are in geographical order from west to east.

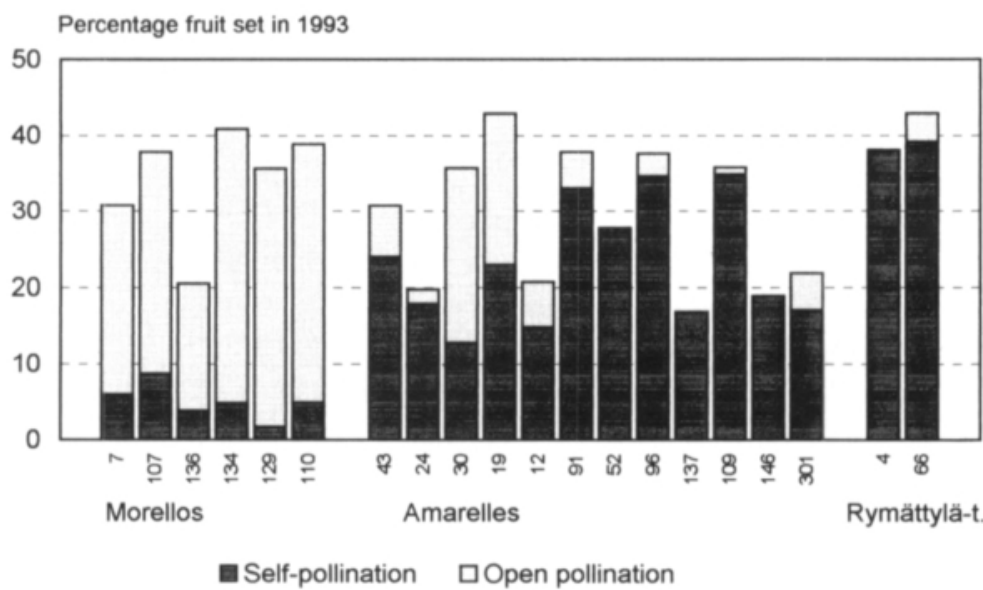

ure 1). It was found that the local races from Western Finland yielded higher percentages of fruit set, both by self-pollination and by open pollination, than the local races from Eastern

Table 2. Percentage fruit sets of sour cherry by self-pollination (self) and by open pollination (open) in 1992 and 1993, and their ratio in 1993.

\begin{tabular}{lrrrrr}
\hline & \multicolumn{4}{c}{ Percentage fruit set } & \\
\cline { 2 - 5 } Local & \multicolumn{2}{c}{1992} & \multicolumn{2}{c}{1993} & self/open \\
race no. & self & \multicolumn{1}{c}{ open } & self & open & $(\%)$ \\
\hline Morellos & 1.3 & 14.1 & 5.2 & 34.3 & 15.5 \\
Amarelles & 4.9 & 9.1 & 23.1 & 27.4 & 94.3 \\
Rymättylä-type & 10.5 & 10.5 & 38.5 & 38.5 & 102.0 \\
Total average & 4.3 & 10.7 & 19.3 & 30.6 & 71.4 \\
\hline
\end{tabular}

Finland. Because of highly random variation in the results it is impossible to say which local races are self-compatible (Saarimäki 1994). In general, the percentage fruit sets were in 1993 higher than in 1992. They varied with self-pollination from 2 to 39 , the average being 19.3, and with open pollination from 13 to 43 , the average being 30.6. Amarelle cherries and Rymättylätype cherries proved to be more self compatible than morello cherries $(\mathrm{P}=0.001)$.

Local races recommended for further study are indicated in Table 1 and the local races selected for a comparative trial are presented in Table 3. Both Tuusniemi and Pihtipudas local races, which were added to the clone archive in 1995, were also selected for a comparative trial. Additionally, some local races were selected for further use in plant breeding (Table 4). 
Palonen, P. et al. Prunus clone archive in Finland: sour cherry

Table 3. Local races of sour cherry selected for a comparative trial.

\begin{tabular}{|c|c|c|c|c|c|c|c|c|c|c|}
\hline No. & Origin & $\begin{array}{l}\text { Season of } \\
\text { flowering }\end{array}$ & $\begin{array}{c}\text { Fruit set }{ }^{*} \\
1-9\end{array}$ & $\begin{array}{c}\text { Season of } \\
\text { ripening }\end{array}$ & $\begin{array}{c}\left.\text { Form }{ }^{* *}\right) \\
1-5\end{array}$ & $\begin{array}{c}\text { Weight } \\
\mathrm{g}\end{array}$ & $\begin{array}{l}\text { Colour } \\
1-9^{\cdots * *}\end{array}$ & $\begin{array}{c}\text { Stalk } \\
\mathrm{mm}\end{array}$ & Pit $\%$ & $\begin{array}{l}\text { Soluble } \\
\text { solids } \%\end{array}$ \\
\hline \multicolumn{11}{|c|}{ Morellos } \\
\hline 7 & Rymättylä & medium & 7 & late & 1 & 2.7 & $8-9$ & 35 & 11.1 & 14.7 \\
\hline 122 & Juva & medium & 7 & late & 1 & 2.7 & $8-9$ & 40 & 10.0 & 14.8 \\
\hline \multicolumn{11}{|c|}{ Amarelles } \\
\hline 24 & Masku & early & 7 & early & $1-2$ & 2.3 & 6 & 30 & 7.9 & 17.5 \\
\hline 85 & $?$ & early & 9 & early & 2 & 3.1 & 5 & 30 & 7.1 & 14.2 \\
\hline 91 & Nurmijärvi & early & 7 & early & 1 & 2.4 & 5 & 35 & 8.8 & 16.4 \\
\hline 93 & Kärkölä & medium & 7 & medium & $1-2$ & 2.8 & 6 & 35 & 7.1 & 14.4 \\
\hline 96 & Hollola & late & 9 & med. -late & 2 & 2.6 & 1 & 29 & 8.8 & 11.9 \\
\hline 101 & Kuusankoski & medium & 9 & medium & $1-2$ & 2.5 & 4 & 35 & 10.0 & 13.7 \\
\hline 104 & Kotka & medium & 8 & medium & 2 & 2.8 & 4 & 30 & 7.6 & 13.2 \\
\hline 109 & Pyhtää & medium & 9 & medium & $1-2$ & 2.5 & 4 & 35 & 10.0 & 13.2 \\
\hline 137 & Laukaa & medium & 8 & medium & 1 & 2.6 & $6-7$ & 30 & 8.1 & 15.1 \\
\hline 301 & $?$ & early & 8 & early & 2 & 2.3 & 7 & 30 & 9.8 & 15.0 \\
\hline \multicolumn{11}{|c|}{ Rymättylä-type } \\
\hline 10 & Rymättylä & early & 9 & medium & 2 & 2.6 & 4 & 25 & 7.7 & 13.2 \\
\hline 37 & Turku & early & 9 & medium & 2 & 2.6 & 5 & 25 & 7.5 & 15.0 \\
\hline
\end{tabular}

*) Fruit set ranges from 1 to $9,1=$ no fruit set, $9=$ very high yielding

"*) Form: 1 = kidney, 2 = flat-round, 3 = round, 4 = elongated, 5 = heart

${ }^{\cdots *}$ Colour ranges from 1 to 9,1 being the most light-coloured (bright red) and 9 being the darkest (black red).

During the documentation period no pests were detected. However, brown rot (Monilia sp.) destroyed some sour cherry fruits and in 1994,

Table 4. Local races of sour cherry selected for further use in plant breeding, and the special properties of each.

\begin{tabular}{ll}
\hline No. Origin & Special properties \\
\hline 66 Sammatti & $\begin{array}{l}\text { Fruit set is very high. The fruits are big } \\
\text { but tasteless and sour. } \\
139 \text { Toivakka }\end{array}$ \\
$\begin{array}{l}\text { The tree is very decorative, both in } \\
\text { flowering and at harvest. Fruit set is } \\
\text { high, but the fruits are small and without } \\
\text { flavour. } \\
144 \text { Anttola }\end{array}$ & $\begin{array}{l}\text { The fruits are big, sweet and have an } \\
\text { exceptionally good aroma. Fruit } \\
\text { set is poor. } \\
\text { The fruits are rather sweet and well } \\
\text { tasting. Fruit set is poor. } \\
\text { The only Prunus avium in the clone } \\
\text { archive. The fruits are small and sweet. }\end{array}$ \\
& Fruit set is poor.
\end{tabular}

bacterial canker (Pseudomonas sp.) symptoms were observed in some trees. In 1995 and 1996, symptoms, including leaf necroses, shoot dieback and even dying of individual trees, had spread throughout P. cerasus material. Symptoms indicated either Pseudomonas syringae pv. syringae or $P$. s. pv. morsprunorum infection (Bech 1992, Sobiczewski and Jones 1992). The identification of these pathogens has so far not been succesful.

\section{Discussion}

Evaluation of sour cherry fruits is greatly affected by their degree of maturity. The optimum ripening date is difficult to assess visually, as sour cherries reach full maturity up to two weeks after they seem to be mature, based on fruit col- 


\section{AGRICULTURAL AND FOOD SCIENCE IN FINLAND}

\section{Vol. 7 (1998): 391-399.}

our. During this time many of their properties, such as taste, aroma, content of soluble solids and even fruit size continue to change significantly (Nyman 1990).

Because of wide genetic variation, differences between the three sour cherry groups in the clone archive are not distinct. Diversity is continuous, and a lot of variation occurs within each group. This is due to the fact that, historically, new progenies have arisen from seeds, and have been spread through propagating root suckers. A clear difference in geographical distribution between morellos and amarelles in Finland was observed, morelles being of eastern and amarelles of western origin. This most likely reflects their different ways of entry into the country, and is in agreement with findings of Kolesnikova (1975) (Ref. Iezzoni et al. 1990), who divided sour cherry cultivars into two ecotypes based on morphological differences and cold-hardiness: i.e. western European and middle-Russian ecotypes. In Southern and Western Europe amarelle type cherries have been favoured, while in Eastern and Northern Europe and Russia more cold hardy morello type cherries have been favoured (Yushev 1975, 1977, Ref. Iezzoni et al. 1990).

On the basis of our results from 1993, the morello type local races were regarded as partly self-compatible, their percent fruit set by selfpollination varying between 1.5 and 15 (Redalen 1984a). The small fruit size of most morellos in the Prunus clone archive is evidence of them being mainly forms of 'Yleinen ruskeakirsikka' ('Common brown cherry'), which is self-incompatible, and has been widely cultivated in Finland because of its hardiness (Collan 1929, 1934). The other common morello type cultivar is 'Varjomorelli'. It is one of the oldest sour cherry cultivars in Finland and totally self-compatible (Meurman 1947, Nilsson 1989).

Amarelle type local races in the clone archive proved to be self-compatible. They are supposed to be mainly forms of 'Yleinen kuulasmarja' ('Common amarelle'), which has been widely cultivated in Finland, as far as the northern boundary of cherry cultivation (Collan 1929, Meurman 1947). In amarelle type local races, especially in Rymättylä type cherries, also some characteristics of Duke cherry cultivar 'Iso kuulasmarja' ('Big amarelle') were observed.

In comparison with sour cherries from other Nordic countries, native sour cherries in Finland have relatively small fruits. The fruit size is, however, greatly affected by growing conditions. In our study, the mean weight of fruits was $2.4 \mathrm{~g}$ for morellos, $2.5 \mathrm{~g}$ for amarelles and $2.8 \mathrm{~g}$ for Rymättylä type cherries. In a cultivar trial in Sweden, the average fruit weight of sour cherry cultivars was $4.7 \mathrm{~g}$ (Hintze 1976). In Denmark the average fruit weight was $4.3 \mathrm{~g}$ for morello cultivars, and $4.6 \mathrm{~g}$ for amarelle cultivars (Christensen 1990), and in Norway $4.08 \mathrm{~g}$ and $4.32 \mathrm{~g}$ for morellos and amarelles, respectively (Vestrheim 1986).

Based on the results of this study, native morello type cherries in Finland are less selfcompatible than morello cultivars in Norway. In contrast, the Finnish amarelle type cherries are more self compatible than those in Norway. For morellos, the average percents fruit set by selfpollination were in our study 1.3, and 5.2, in 1992 and 1993, respectively, and in Norway it was 14.7 (Redalen 1984b). The average percents final fruit set by self-pollination were for amarelles 4.9 and 23.1, in 1992 and in 1993, respectively. For Norwegian amarelle cultivars it was 5.0. The average content of soluble solids in local races selected for a comparative trial was $14.5 \%$. It is equal to the threshold value determined by Vangdal (1980) for sweet cherries.

In regard to its annual growth rhythm, sour cherry is a potential new fruit crop in Finland. The cherries ripen early enough, and can thus be cultivated also further north, if only winter hardiness is secured. In order to find new commercial sour cherry cultivars adapted to Nordic conditions, the most promising local races from each group were selected for a comparative trial. The aim is to select a few cultivars suitable for fresh fruit production, home gardens and even for industrial production. For example, in Denmark, where sour cherry is the largest fruit crop next to apple, the production has mostly been concentrated on clones of local seedlings, the 


\section{AGRICULTURAL AND FOOD SCIENCE IN FINLAND}

Palonen, P. et al. Prunus clone archive in Finland: sour cherry

most important of them being 'Stevnsbär' (Christensen 1990). Through micro-propagation it is possible to produce own-rooted sour cherry trees. The advantage of this is that own-rooted trees are capable of regrowth even after severe win- ters, when the trunk of the tree is damaged or died.

Acknowledgments. Financial support from the Nordic Gene Bank is greatfully acknowledged.

\section{References}

Bech, K. 1992. Susceptibility to bacterial canker in sour cherry varieties. Orchard observations and inoculation trials. Journal of Phytopathology 134: 238-246.

Collan, O. 1929. Hedelmän- ja marjanviljelyksen kăsikirja. Otava. Helsinki. 424 p.

- 1934. Suomen hedelmänviljelys hedelmätarhojamme v. 1929 kohdanneen tuhon valossa. Valtion maatalouskoetoiminnan julkaisuja no. 60. Helsinki. 68 p.

Christensen, J. V. 1990. A review of an evaluation of 95 cultivars of sour cherry. Tidskrift for planteavl (Danish Journal of Plant and Soil Science) 94: 51-63.

Hillig, K. W. \& lezzoni, A. F. 1988. Multivariate analysis of sour cherry germplasm collection. Journal of American Society of Horticultural Science 113: 928-934.

Hintze, S. 1976. Sortförsök med surkörsbär. Konsulentavdelningens stencilserie. Trädgárd 103. Sveriges Lantbrukshögskolan. Alnarp.

lezzoni, A., Schmidt, H. \& Albertini, A. 1990. Cherries (Prunus). Acta Horticulturae 290: 111-173.

Kolesnikova, A. F. 1975. Breeding and some biological characteristics of sour cherry in Central Russia. Orel, U.S.S.R.: Priokstoc izdatel'stvo. (Ref. Iezzoni et al. 1990).

Meurman, O. 1947. Suomen hedelmäpuut ja viljellyt marjat. II Päärynät, luumut, kirsikat ja marjat. Oy Suomen Kirja. Helsinki. 351 p.

Michigan State University. 1989. User's guide to MSTAT-C. Michigan.

Nilsson, A. 1989. Vảra päron-, plommon- och körsbärsorter. Nordiska Genbanken. Örebro. 370 p.

Nyman, I. 1990. Hapan ja imelä kirsikka. In: Suomalainen puutarha. Marjat ja hedelmät. Weilin + Göös. p. $238-247$.

Redalen, G. 1984a. Fertility in sour cherries. Gartenbau- wissenschaft 49: 212-217.

- 1984b. Pollinering av plomme og surkirsebær. Gartneryrket 74: 446-350.

Saarimäki, S. 1994. Pölyttyminen hapankirsikan (Prunus cerasus L.) hedelmänmuodostuksessa. Master's thesis. Horticulture. Department of Plant Production. University of Helsinki. $43 \mathrm{p}$.

Sobiczewski, P. \& Jones, A. L. 1992. Effect of exposure to freezing temperatures on nekrosis in sweet cherry shoots inoculated with Pseudomonas syringae pv. syringae or P. s. pv. morsprunorum. Plant Disease 76: 447-451.

Trajkovski, V., Fernqvist, I., Bjurman, B.-O. \& Rumpunen, K. 1992. Genetiska resurser hos nytto- och prydnadsväxter. (Summary: Genetic resources in horticulture.) Balsgárd - Institutionen för hortikulturell växtförädling. Verksamhetsberättelse 1990-1991. Sveriges Lantbruksuniversitet. Alnarp. p. 132-139.

Vangdal, E. 1980. Threshold values of soluble solids in fruit determined for fresh fruit market. Acta Agriculturae Scandinavia 30: 445-448.

Vestrheim, S. 1986. Forsøk med 11 surkirsebærsortar. (Summary: Trial of 11 sour cherry varieties). Institutt for fruktdyrkning, Melding nr. 116. Meldingar fra Norges Landbrukhøgskole 65: 11.

Yussef, A. 1975. Morphological characters of the leaf in sour cherry and their use in the classification of varieties. Byulletin Vsesojusniy Ordena Lenina 54: 3440 (in Russian). (Ref. lezzoni et al. 1990).

- 1977. Morphological characters of the fruit in sour cherry and their use in the classification of varieties. Byulletin Vsesojusniy Ordena Lenina 75: 27-31 (in Russian). (Ref. lezzoni et al. 1990). 
Vol. 7 (1998): 391-399.

\title{
SELOSTUS
}

\section{Pohjoismaisen geenipankin Prunus-kokoelma Suomessa I Hapankirsikkakannat}

\author{
Pauliina Palonen, Marjatta Uosukainen, Eeva Laurinen, Päivi Parikka ja Jyri Kankila \\ Maatalouden tutkimuskeskus ja Helsingin yliopisto
}

Maatalouden tutkimuskeskuksen Hämeen tutkimusasemalla sijaitsevan Pohjoismaisen geenipankin Prunus-kokoelman hapankirsikkakannoissa (Prunus cerasus $\mathrm{L}$.) esiintyvää geneettistä muuntelua kartoitettiin arvioimalla kantojen morfologisia ominaisuuksia. Vuonna 1993 oli elossa 118 kirsikkapuuta, jotka edustivat 78 eri paikalliskantaa. Jokaisesta puusta laadittiin 42 ominaisuutta sisältävä kuvaus, joka tallennettiin Pohjoismaisen geenipankin BIRS-tietokantaan.

Perinnöllistä vaihtelua esiintyi runsaasti. Ominaisuuksiensa perusteella kirsikkakannat jaettiin kolmeen ryhmään. 32 kantaa oli pääasiassa itäsuomalaista alkuperää olevia morelleja, joiden hedelmämehu on tummanpunaista. 40 kantaa oli kuulasmarjatyyppisiä, joiden hedelmämehu on vaaleaa. Kuulasmarjat oli kerätty pääasiassa eteläisimmästä Suomesta. Viisi Rymättylästä, Turusta ja Sammatista rekisteröityä kuulasmarjakantaa erosivat muista kuulasmarjoista, ja niille ehdotetaan annettavan nimeksi rymättylätyyppiset hapankirsikat. Vain yksi kokoelman kannoista oli imeläkirsikka. Kuulasmarjat ja rymättylätyyppiset hapankirsikat osoittautuivat itsepölytyskykyisiksi ja morellit osittain itsepölytyskykyisiksi.

Kartoituksen yhteydessä kaikkien kirsikkakantojen mahdollinen käyttöarvo arvioitiin. Tärkeimpiä kriteereitä olivat puun koristearvo, satoisuus, sadon laatu, tauti- ja tuholaiskestävyys ja talvenkestävyys. Lupaavimmat kirsikkakannat valittiin kantavertailukokeeseen, jonka tavoitteena oli löytää Suomen oloihin soveltuvia lajikkeita. Lisäksi joitakin kantoja valittiin jonkin hyvän ominaisuutensa vuoksi käytettäväksi jalostuksessa. Hapankirsikan käyttöä hedelmänviljelyssä saattaa rajoittaa alttius Pseudomonas-syringae pv. syringae ja $P$. s. pv. morsprunorum-bakteereille. 